\title{
Biodiesel Production from Castor Oil and Its Application in Diesel Engine
}

\author{
S. ISMAIL ${ }^{1}$, S. A. ABU*, R. REZAUR ${ }^{3}$ AND H. SININ $^{4}$
}

\begin{abstract}
In this study, the optimum biodiesel conversion from crude castor oil to castor biodiesel (CB) through transesterification method was investigated. The base catalyzed transesterification under different reactant proportion such as the molar ratio of alcohol to oil and mass ratio of catalyst to oil was studied for optimum production of castor biodiesel. The optimum condition for base catalyzed transesterification of castor oil was determined to be 1:4.5 of oil to methanol ratio and $0.005: 1$ of potassium hydroxide to oil ratio. The fuel properties of the produced CB such as the calorific value, flash point and density were analyzed and compared to conventional diesel. Diesel engine performance and emission test on different $\mathrm{CB}$ blends proved that $\mathrm{CB}$ was suitable to be used as diesel blends. $\mathrm{CB}$ was also proved to have lower emission compared to conventional diesel.
\end{abstract}

Key words: biodiesel, transesterification, castor oil, diesel engine, emission; conversion

Petroleum fuels play a very important role in the development of various industries, transportations, agriculture sector and to meet many other basic human needs in modern civilization. These fuels are limited and depleting day by day as the consumption increase very rapidly. Moreover, the use of petroleum fuel has caused a lot of environmental problems by the high emission of harmful gases. A global movement towards generation of environmentally friendly yet renewable fuel is therefore under way to help meet the increased energy demands. Biofuel had become one of the most promising alternatives for petroleum fuels.

Biodiesel is the potential biofuel that can easily being produced from vegetable oil.
Biodiesel has become an interesting alternative fuel over conventional diesel for decades. Biodiesel is suitable to be used in diesel engine due to the similar properties to conventional diesel in terms of power and torque and none or very minor engine modification is required (Mushtaq et al. 2011). Moreover, biodiesel is biodegradable which will results in less environmental impact upon accidental release to the environment (Janaun \& Ellis 2010).

Biodiesel has many important technical advantages over conventional diesel such as inherent lubricity, low toxicity, derivation from a renewable and domestic feedstock, superior flash point, negligible sulphur content and lower exhaust emissions (Moser 2009). Biodiesel had been used widely as a blend with diesel. The

\footnotetext{
${ }^{1}$ Department of Chemical Engineering, Faculty of Engineering, Universiti Malaysia Sarawak, 94300 Kota Samarahan, Sarawak, Malaysia

2 Department of Mechanical Engineering, Faculty of Engineering, Universiti Malaysia Sarawak, 94300 Kota Samarahan, Sarawak, Malaysia.

${ }^{3}$ Department of Chemical Engineering, Faculty of Engineering, Universiti Malaysia Sarawak, 94300 Kota Samarahan, Sarawak, Malaysia.

${ }^{4}$ Pusat Pengajian Pra-Universiti, Universiti Malaysia Sarawak, 94300 Kota Samarahan,Sarawak. Malaysia

* Corresponding author (e-mail: aasaleh@feng.unimas.my)
} 
use of biodiesel as diesel blends will promote cleaner emission with less soot particles and whiter smoke. It also helps in reducing engine wear by lubrication and produces less sulphur emission. A biodiesel lifecycle study in 1998 which was jointly sponsored by the U.S. Department of Energy and the U.S. Department of Agriculture concluded biodiesel reduces carbon dioxide emissions by 78 percent compared to petroleum diesel. The $\mathrm{CO}_{2}$ released into the atmosphere when biodiesel burned is recycled by plants, which produce more oxygen (Petracek 2014).

Among the common vegetable oils used as feedstock for the production of biodiesel are soybean, rapeseed, castor, jatropha and palm oil. Castor oil is one of the promising feedstock for biodiesel production. Castor oil is produced by means of extraction from castor bean. Castor oil is distinguished by its high content (over $85 \%$ ) of ricinoleic acid. No other vegetable oil contains so high a proportion of fatty hydroxyacids. Castor oils have high molecular weight $(298)$, low melting point $\left(5^{\circ} \mathrm{C}\right)$ and very low solidification point $\left(-12^{\circ} \mathrm{C}\right.$ to $\left.-18^{\circ} \mathrm{C}\right)$ that make it industrially useful, most of all it is has the highest and most stable viscosity of any vegetable oil (Shrirame et al. 2011).

The chemical structure of castor oil is of great interest because of the wide range of reactions it affords to the oleochemical industry and the unique chemicals that can be derived from it. These derivatives are considerably superior to petrochemical products since they are from renewable sources, bio-degradable and eco-friendly (Nielsen et al. 2011). Recent research had concerns in the using of castor oil as a feedstock for biodiesel production. As castor oil is non-edible, there is no issue of competition with the food market and it can be the promising source of feedstock for biodiesel production.

In this study, the acid-based catalyzed transesterification of castor oil was carried out to determine the optimum reaction condition for the production of castor biodiesel. Then, the fuel properties such as density, flash point and calorific value was analyzed and compared to conventional diesel. Engine performance and emission of castor biodiesel was also tested using various biodiesel blends and compared to the conventional diesel.

\section{METHODOLOGY AND MATERIALS}

In this study, crude castor oil was extracted from castor bean by using mechanical and solvent extraction. The castor beans used was obtained from a local company. The acid value of the crude castor oil was determined by titrimetry. The castor oil was converted into biodiesel by using two-step transesterification processes. In this process, the first step is acidcatalyzed esterification used to convert free fatty acids (FFA) in castor oil to methyl ester, followed by base-catalyzed transesterification using potassium hydroxide as a catalyst with methanol.

In the second step, potassium hydroxide was dissolved in methanol and the mixture is then heated up to $60^{\circ} \mathrm{C}$ to react accordingly to form methoxide. On the other hand, the pretreated oil in step 1 was then heated up to $60^{\circ} \mathrm{C}$. The heated oil was mixed with the methoxide and the solution was shaken at 250 r.p.m. for $2 \mathrm{~h}$ by using orbital shaker. The volume ratio of methanol to oil used was 1:4.0, 1:4.5 and 1:5.0 while the volume ratio of potassium hydroxide catalyst to oil used was $0.0025: 1,0.0050: 1$ and $0.0075: 1$. The volume ratio of alcohol to oil was kept constant when the catalyst amounts were being manipulated. The volume ratio of catalyst to oil was kept constant when the amount of alcohol was being manipulated. After completing the process, the mixture was allowed to settle for $8 \mathrm{~h}$ and then the mixture was poured into separatory funnels.

The lower layer of glycerol, extra methanol, catalyst and other byproducts were removed. 
The upper layer of methyl ester or biodiesel was washed several times with de-sterilized water until the washing water become neutral. The biodiesel layer was filtered to remove impurities and then the biodiesel was heated up to $100^{\circ} \mathrm{C}$ to remove any remaining water. The biodiesel was the tightly sealed and kept for storage.

Biodiesel testing was carried out to compare the properties and performances of castor biodiesel and conventional diesel. The density, flash point and calorific value are measured respectively using density meter, multi-flash flash point tester and bomb calorimeter. Emission analyses were carried out using Flue Gas Analyzer. Castor biodiesel and conventional diesel were tested using FT-IR Shimadzu Iraffinity-1 Spectrophotometer for component analysis.

Diesel engine test was performed using Techno-mate, TNM-TDE-700 machine. The diesel engine testing was done three times with each blend of biodiesel. The blending percentage of biodiesel with diesel was set to $0 \%, 10 \%, 20 \%, 30 \%, 40 \%, 50 \%$ and they are mentioned as B10, B20, B30, B40, B50. Important values such as motor speed, output voltage, output current and time for $20 \mathrm{ml}$ fuel flow were recorded. The brake load for the diesel engine testing was fixed at $120 \mathrm{~N}$ and the radius of brake arm was set to $0.5 \mathrm{~m}$.

\section{RESULTS AND DISCUSSIONS}

\section{Measurement of Free Fatty Acid (FFA) in Crude Castor Oil}

Measurement of FFA in crude castor oil is essential for the decision of the method of transesterification for biodiesel production. From the titration method, the acid value of FFA in crude castor oil was determined to be between $20 \%$ to $23 \%$, which is higher than $4 \%$. The best conversion method for oil with free fatty acid higher than $4 \%$ was twosteps transesterification where FFA value is reduced at the first step (acid esterification) before proceeding to the second step (base transesterification).

\section{Optimization of Biodiesel Production by Manipulation of Catalyst and Alcohol Amount}

For the first set of experiment, the amount of catalyst was set as the manipulated variable while the amount of methanol was set as the constant variable. From Table 1, it is observed that the highest yield of biodiesel was achieved with potassium to oil ratio of 0.0050:1. However, the biodiesel yield before and after the optimal amount of catalyst was noted to be lower. In the case of the catalyst shortage (0.0025:1 ratio), the biodiesel yield percentage was $60 \%$ as catalyst was exhausted before all the crude oil was converted to biodiesel while in the case of excess catalyst ( $0.0075: 1$ ratio), the yield percentage was at $55 \%$ as excess catalyst attributed to soap formation which decreased the production of biodiesel.

For the second set of experiment, the amount of methanol was set as the manipulated variable while the amount of catalyst was set as the constant variable. From Table 2, it is observed that the highest yield of biodiesel was achieved with the 1:4.5 of oil-to-methanol ratio. The biodiesel yield was also affected by the amount of methanol used. The shortage

Table 1. Biodiesel Yield Percentage for Different Amount of KOH (catalyst).

\begin{tabular}{c|cc}
\hline $\mathrm{KOH}$ to oil ratio $(\mathrm{v} / \mathrm{v})$ & Castor biodiesel produced $(\mathrm{ml})$ & Biodiesel yield $(\%)$ \\
\hline $0.0025: 1$ & 12 & 60 \\
$0.005: 1$ & 13 & 65 \\
$0.0075: 1$ & 11 & 55 \\
\hline
\end{tabular}


of methanol used will decrease the yield of biodiesel significantly. Excess methanol (1:5.0 ratio) contributed to methanol wastage and difficulty in the end product purification. Excess methanol increased the solubility of glycerol which was the by-product formed in biodiesel transesterification thus, it caused difficulty in the purification of biodiesel. Shortage of methanol (1:4.0 ratio) attributed to the lack of solution for the reaction to take place. Thus, it could be concluded that the optimal reactant proportion used to achieve the highest yield of biodiesel produced by base-catalysed transesterification was $0.0050: 1 \mathrm{KOH}$ to oil ratio with $1: 4.5$ of oil to methanol ratio.

\section{FTIR Analysis}

Based on the infrared spectrum of castor biodiesel and conventional diesel Figures 1 and 2, both castor biodiesel and conventional diesel showed the alkane $\mathrm{C}-\mathrm{H}$ bond which lies on the wave numbers from $2800 \mathrm{~cm}^{-1}$ to $3000 \mathrm{~cm}^{-1}$ and alkene $\mathrm{C}-\mathrm{H}$ bond at $1400 \mathrm{~cm}^{-1}$ to $1500 \mathrm{~cm}^{-1}$. Thus, it could be confirmed that both conventional diesel and castor biodiesel had the same functional group of $\mathrm{C}-\mathrm{H}$. However, the conventional diesel had no oxygen group, whereas castor biodiesel showed oxygen functional group of ester $\mathrm{C}-\mathrm{O}$ bond at $1000 \mathrm{~cm}^{-1}$ to $1300 \mathrm{~cm}^{-1}$ and ester $\mathrm{C}=\mathrm{O}$ bond at $1735 \mathrm{~cm}^{-1}$ to $1750 \mathrm{~cm}^{-1}$. The presence

Table 2. Biodiesel Yield Percentage for Different Amount of Methanol.

\begin{tabular}{c|cc}
\hline Oil to methanol ratio $(\mathrm{v} / \mathrm{v})$ & Castor biodiesel produced $(\mathrm{ml})$ & Biodiesel yield $(\%)$ \\
\hline $1: 4.0$ & 9.5 & 47.5 \\
$1: 4.5$ & 10.5 & 52.5 \\
$1: 5.0$ & 7.0 & 35.0 \\
\hline
\end{tabular}

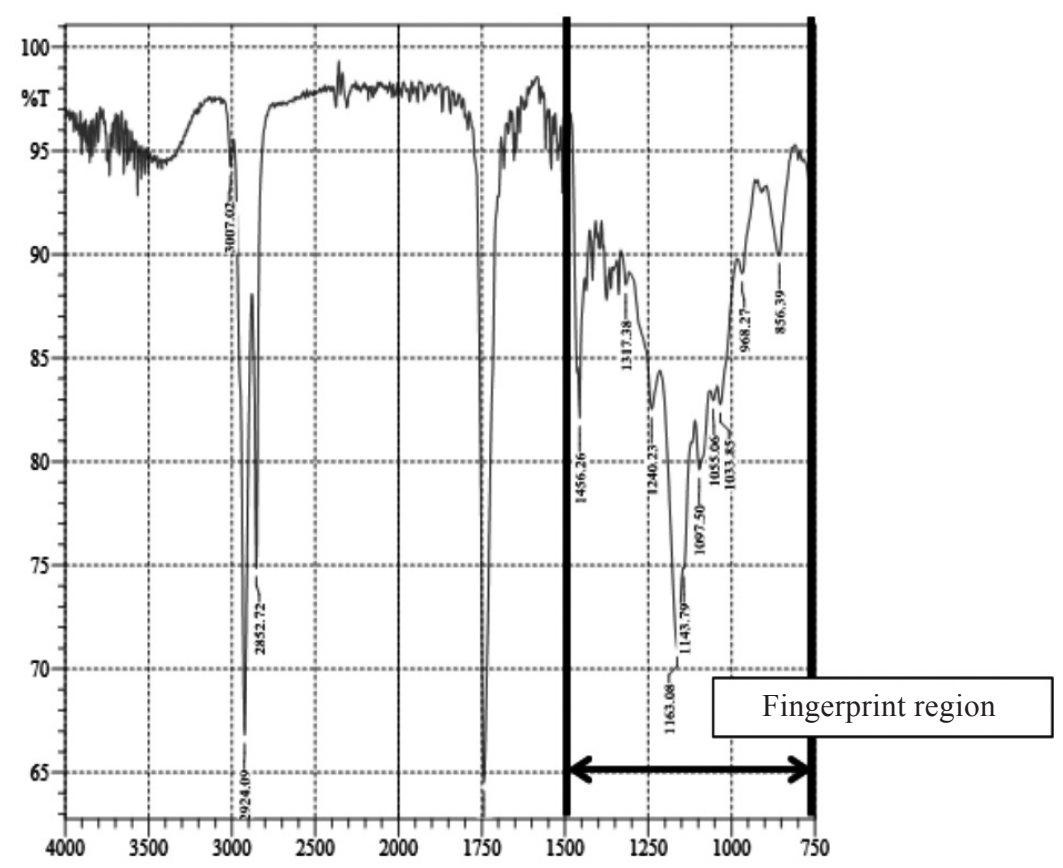

Figure 1. FTIR spectrum of castor biodiesel. 


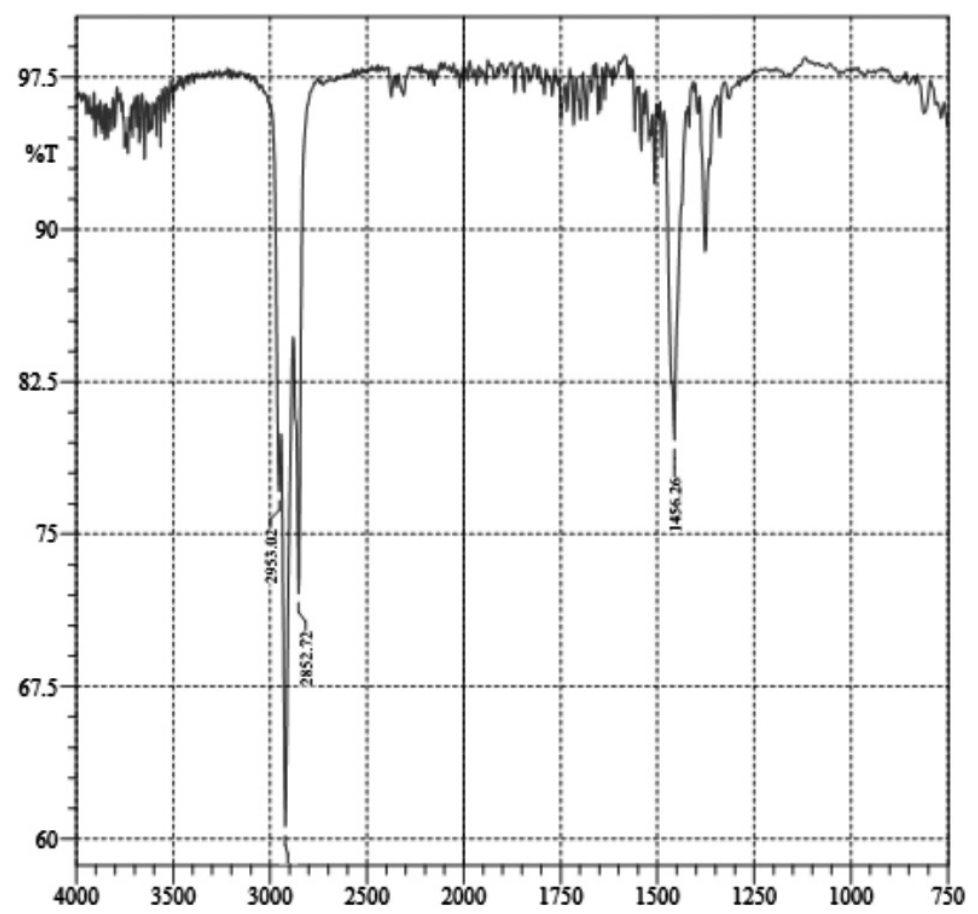

Figure 2. FTIR spectrum of conventional diesel.

of oxygen in biodiesel promotes cleaner and complete combustion. On the other hand, the conventional diesel without any oxygen component produced more black smoke and incomplete combustion during burning .

\section{Fuel Property Analysis of Castor Biodiesel}

\section{Density}

Density value must be maintained within tolerable limits to allow optimal air to fuel ratios for complete combustion in diesel engine (Ibeto et al. 2012). For diesel, the standard range for density value is $848 \mathrm{~kg} / \mathrm{m}^{3}$. For biodiesel, the standard for density value is in the range of $870 \mathrm{~kg} / \mathrm{m}^{3}-900 \mathrm{~kg} / \mathrm{m}^{3}$. For crude castor oil, the density value is in the range of $956 \mathrm{~kg} / \mathrm{m}^{3}-963 \mathrm{~kg} / \mathrm{m}^{3}$. As observed from Table 3, the density for conventional diesel, castor biodiesel and crude castor oil are 841 $\mathrm{kg} / \mathrm{m}^{3}, 921 \mathrm{~kg} / \mathrm{m}^{3}$ and $950 \mathrm{~kg} / \mathrm{m}^{3}$, respectively. It is observed that in comparison to ASTM standards, conventional diesel and crude castor oil conforms to the range while castor biodiesel is sighted to be slightly higher than that of the standard. Higher density value of biodiesel is contributed by the high viscosity of castor oil. The lack of double bond in triglyceride molecule plus long hydrocarbon tail on fatty acid molecule contribute to high viscosity of castor oil (Okullo et al. 2012). High-density biodiesel is not favourable as it can lead to incomplete combustion and particulate matter emissions (Galadima et al. 2008). However, this problem could be solved by blending biodiesel with conventional diesel.

Table 3. The density value for crude castor oil, castor biodiesel and conventional diesel.

\begin{tabular}{c|c}
\hline Sample & Density value $\left(\mathrm{kg} / \mathrm{m}^{3}\right)$ \\
\hline Conventional diesel & 841 \\
Castor biodiesel & 921 \\
Crude castor oil & 950 \\
\hline
\end{tabular}


Calorific value. From Table 4, it was observed that conventional diesel had the highest calorific value followed by crude castor oil and castor biodiesel with the calorific value of $44.803 \mathrm{MJ} / \mathrm{kg}, 38.130 \mathrm{MJ} / \mathrm{kg}$ and 37.908 $\mathrm{MJ} / \mathrm{kg}$. The calorific value for castor biodiesel was slightly lower than that of the conventional diesel, where more amounts of biodiesel was needed to produce the same thermal energy as conventional diesel. Biodiesel has lower calorific value as its composition comprised of additional oxygen functional group and relatively lower hydrocarbon content compared to that of conventional diesel (Mathiyazhagan \& Ganapathi 2011).

Table 4. The calorific value of crude castor oil, castor biodiesel and conventional diesel.

\begin{tabular}{c|c}
\hline Sample & Calorific value $(\mathrm{MJ} / \mathrm{kg})$ \\
\hline Conventional diesel & 44.803 \\
Castor biodiesel & 37.908 \\
Crude castor oil & 38.13 \\
\hline
\end{tabular}

Flash point. Flash point is the temperature that indicates the overall flammability hazards in the presence of air; higher flash point makes for safe handling and storage of biodiesel (Mushtaq et al. 2011). The flash point values for conventional diesel, castor biodiesel and crude castor oil are $75.0^{\circ} \mathrm{C}, 130.0^{\circ} \mathrm{C}$ and $230.0^{\circ} \mathrm{C}$, respectively. From Table 5, it was observed that crude castor oil had the highest value of flash point followed by castor biodiesel and conventional diesel. Castor biodiesel hadhigher flash point value over conventional diesel as biodiesel was more viscous compared to conventional diesel. Flash point was positively correlated with the viscosity of diesel. The higher the viscosity, the higher the boiling point and thus caused higher flash point. Other than that, diesel has branches and lower molecular weight components which lead to a reduction of flash point (Knothe 2010). The high flash points of biodiesel make it suitable to be used as alternative to conventional diesel.

Table 5. The flash point for crude castor oil, castor biodiesel and conventional diesel.

\begin{tabular}{c|c}
\hline Sample & Flash point $\left({ }^{\circ} \mathrm{C}\right)$ \\
\hline Conventional diesel & 75 \\
Castor biodiesel & 130 \\
Crude castor oil & 230 \\
\hline
\end{tabular}

\section{Engine Performance}

Data collected from diesel engine testing were calculated and presented as shown in Table 6. From the results shown, it was observed that the brake horsepower, engine power output and mechanical efficiency were decreasing while the biodiesel blend ratio was increasing. However, the specific fuel consumption increased with the increase of biodiesel blend ratio.

Table 6. Engine performance of various castor biodiesel blends.

\begin{tabular}{c|ccccc}
\hline $\begin{array}{c}\text { Castor } \\
\text { biodiesel } \\
\text { blends }\end{array}$ & $\begin{array}{c}\text { Fuel consumption } \\
\text { rate }(\mathrm{ml} / \mathrm{s})\end{array}$ & $\begin{array}{c}\text { Brake horse } \\
\text { power, BHP } \\
(\mathrm{kW})\end{array}$ & $\begin{array}{c}\text { Engine power } \\
\text { output }(\mathrm{kW})\end{array}$ & $\begin{array}{c}\text { Specific fuel } \\
\text { consumption, } \\
\text { SFC }(\mathrm{ml} / \mathrm{kW})\end{array}$ & $\begin{array}{c}\text { Mechanical } \\
\text { efficiency, } \eta \\
(\%)\end{array}$ \\
\hline B0 & 0.25 & 7.527 & 1.201 & 16.653 & 13.022 \\
B10 & 0.247 & 7.521 & 1.187 & 16.849 & 13.012 \\
B20 & 0.241 & 7.521 & 1.165 & 17.167 & 13.012 \\
B30 & 0.241 & 7.515 & 1.165 & 17.167 & 13.002 \\
B40 & 0.241 & 7.515 & 1.142 & 17.513 & 13.002 \\
B50 & 0.238 & 7.508 & 1.142 & 17.513 & 12.99 \\
\hline
\end{tabular}




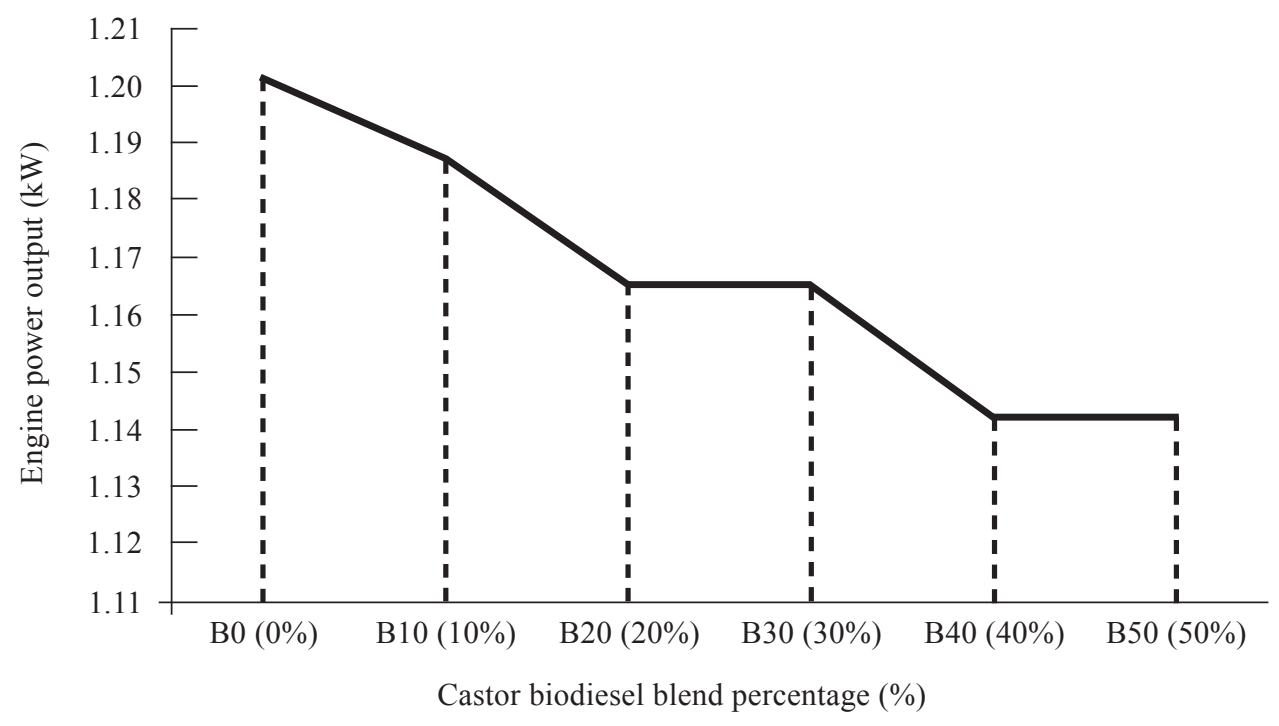

Figure 3. The graph of engine power output versus castor biodiesel blends.

The decrement percentage of the decrease of engine power output for B10, B20, B30, $\mathrm{B} 40$ and $\mathrm{B} 50$ relative to $\mathrm{B} 0$ (conventional diesel) were $1.17 \%, 3.00 \%, 3.00 \%, 4.91 \%$ and $4.91 \%$, respectively. The decrement of engine power output were due to lower energy content per volume of castor biodiesel compared to conventional diesel. However the power output decrement was less than 5\% although 50\% blends of biodiesel were used. This showed that biodiesel was suitable to be used as diesel blends.

From Figure 4, the increment of specific fuel consumption were observed when the blending percentage of biodiesel increased. The increment percentage for for B10, B20, $\mathrm{B} 30, \mathrm{~B} 40$ and $\mathrm{B} 50$ relative to $\mathrm{B} 0$ (conventional diesel) were $1.18 \%, 3.09 \%, 3.09 \%, 5.16 \%$, $5.16 \%$ respectively. The higher specific fuel consumption of those higher percentage blends ratio was due to the fact that biodiesel had lower calorific value than the conventional diesel. More fuel was consumed to produce $1 \mathrm{~kW}$ of power compared to conventional diesel. Furthermore, higher containment of oxygen in biodiesel was also the cause of the lower calorific value. Despite the better combustion of biodiesel compared to the conventional diesel, the oxygen in biodiesel took up space in the blend and slightly increased the fuel consumption rate. Thus, higher oxygen content in biodiesel leads to the low calorific value of Biodiesel (Islam et al. 2014).

Based on Figure 5, the mechanical efficiency decreased slightly with the increase of blending percentage of biodiesel. The decrement noted for B10, B20, B30, B40 and B50 were $0.08 \%, 0.08 \%, 0.15 \%, 0.15 \%, 0.25 \%$, respectively. The decrement was however, insignificant as it was less than $1 \%$. The lower mechanical efficiency of biodiesel is mainly due to the low volatility and high density of ester which affects the automization of the fuel and thus leads to poor combustion (Islam et al. 2014).

\section{Emission Analysis}

From Table 7, it was observed that castor biodiesel had lower emission of carbon monoxide $(\mathrm{CO})$, sulphur dioxide $\left(\mathrm{SO}_{2}\right)$ and nitrogen dioxide $\left(\mathrm{NO}_{2}\right)$ compared to conventional diesel. Lower emission of $\mathrm{CO}$ and $\mathrm{SO}_{2}$ for biodiesel were due to the additional 


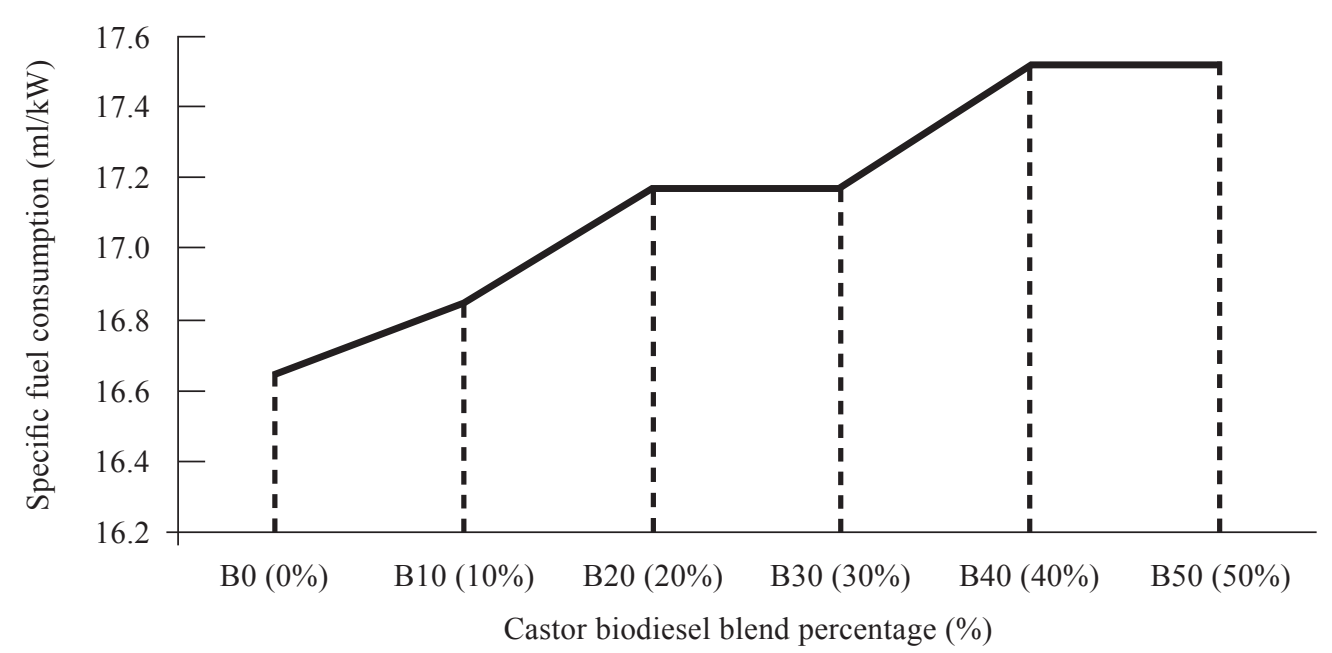

Figure 4. The graph of specific fuel consumption versus castor biodiesel blends.

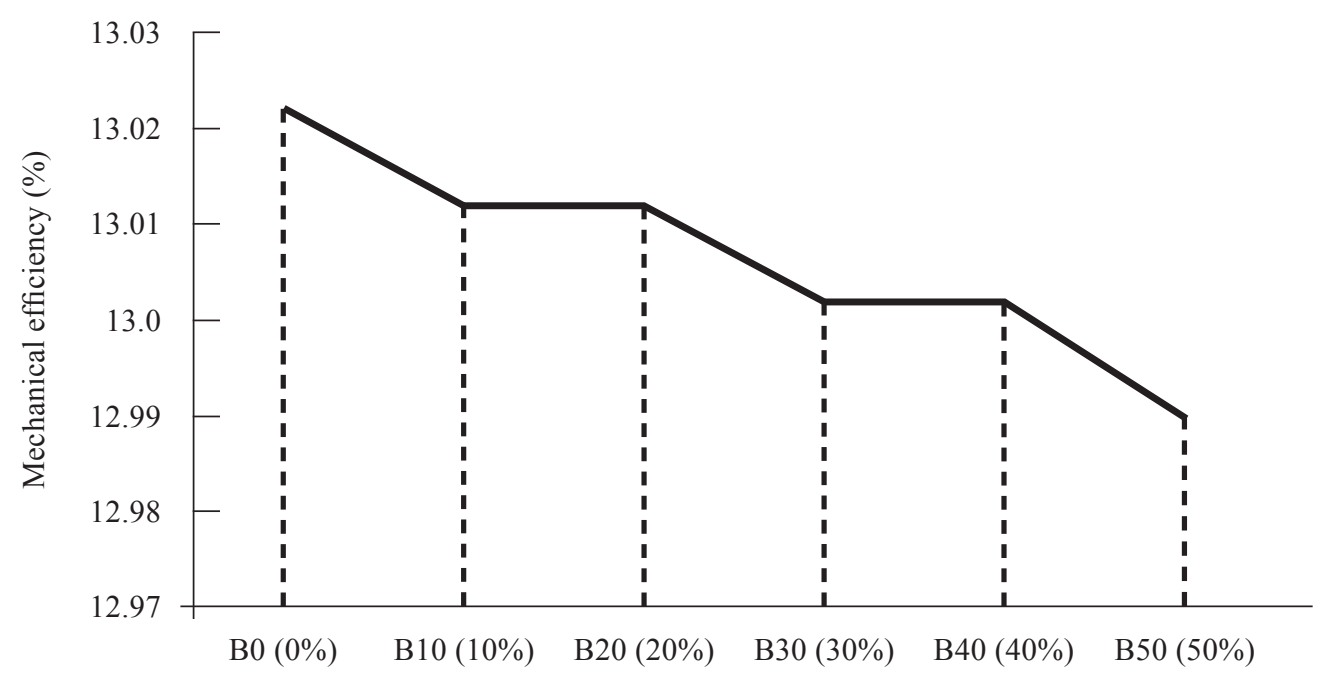

Castor biodiesel blend percentage, $\%$

Figure 5. The graph of mechanical efficiency versus castor biodiesel blends.

Table 7. The emission analysis for conventional diesel and castor biodiesel.

\begin{tabular}{c|cccc}
\hline Sample & $\mathrm{CO}$ (p.p.m.) & $\mathrm{SO}_{2}$ (p.p.m.) & $\mathrm{NO}_{2}$ (p.p.m.) & $\mathrm{NO}_{\mathrm{x}}$ (p.p.m.) \\
\hline Conventional diesel & 79 & 3 & 0.4 & 2 \\
Castor biodiesel & 60 & 2 & 0.2 & 3 \\
\hline
\end{tabular}


oxygen content in biodiesel, which improved the combustion in the cylinders of diesel engine. Higher nitrogen oxide $\left(\mathrm{NO}_{\mathrm{x}}\right)$ emission for biodiesel is due to the oxygen concentration in biodiesel causing the formation of $\mathrm{NO}_{\mathrm{x}}$ in the emission gas (Christopher et al. 2001). $\mathrm{NO}_{\mathrm{x}}$ emission is primarily a function of total oxygen inside the combustion chamber, temperature, pressure, compressibility, and velocity of sound. Furthermore, the increase of $\mathrm{NO}_{\mathrm{x}}$ emission is due to the higher cetane number of biodiesel which will reduce the ignition delay (Fazal et al. 2011). The increase of $\mathrm{NO}_{\mathrm{x}}$ emission is a result of the reduced ignition delay. However, the $\mathrm{NO}_{\mathrm{x}}$ emissions can be reduced through engine tuning or using exhaust catalytic converter (Leung 2001; Enweremadu $\&$ Mbarawa 2009). Moreover, the use of exhaust gas recirculation (EGR) can reduce the $\mathrm{NO}_{\mathrm{x}}$ emission too where the temperature of exhaust gas is reduced when passing through the combustion chamber. In overall, castor biodiesel emitted cleaner gas emissions than conventional diesel and the combustion is more complete. These properties make biodiesel suitable to be used as an alternative to conventional diesel or as a blend to lower the emission of conventional diesel.

\section{CONCLUSION}

The optimum reactant proportion for base catalyzed transesterification of castor oil was determined to be $1: 4.5$ of oil to methanol ratio, and $0.005: 1$ of potassium hydroxide to oil ratio. The additional content of oxygen in castor biodiesel promoted complete combustion in diesel engine thus, it led to lower emissions. The high flash point of castor biodiesel made it safe for handling and storage. Reduction of mechanical efficiency and power output of castor biodiesel compared to conventional diesel was minor and tolerable. Lower emission of castor biodiesel compared to conventional diesel proved it as a green fuel. Castor biodiesel was a suitable fuel to be used as diesel blends.

\section{ACKNOWNLEDGEMENT}

This study was supported by the Department of Mechanical and Manufacturing Engineering, Faculty of Engineering, University Malaysia Sarawak, Malaysia.

Date of submission: September 2014

Date of acceptance: November 2014

\section{REFERENCES}

Christopher, C, Enweremadu, Rutto, HL \& Peleowo, N 2001, 'Performance evaluation of a diesel engine fueled with methyl ester of shea butter', World Academy of Science, Engineering and Technology, vol. 5.

Enweremadu, CC \& Mbarawa, MM 2009 ‘Technical aspects of production and analysis of biodiesel from used cooking oil-a review', Renewable and Sustainable Energy Reviews, vol. 13, pp. 2205-2224.

Fazal, MA, Asma, H \& Masjuki, HH 2011, 'Biodiesel feasibility study: an evaluation of material compatibility, performance, emission and engine durability', Renewable and Sustainable Energy Reviews, vol. 15, pp. 1314-1324.

Galadima, A, Garba, ZN \& Ibrahim, BM 2008, 'Homogeneous and heterogeneous transesterification of groundnut oil for synthesizing methyl biodiesel', International Journal of Pure and Applied Sciences, vol. 2, pp. 138-144.

Ibeto, CN, Okoye, COB \& Ofoefule, AU 2012, 'Comparative study of physicochemical characterization of some oils as potential feedstock for biodiesel production', Renewable Energy, vol. 3.

Islam, MS, Ahmed, AS, Islam, A, Aziz, SA, Xian, LC \& Mridha, M 2014, 'Study on emission and performance of diesel engine using castor biodiesel', Journal of Chemistry, vol. 8.

Janaun, J \& Ellis N 2010, 'Perspectives on biodiesel as a suitable fuel', Renewable and Sustainable Energy Reviews, vol. 14, pp. 1312-1320.

Knothe, G 2010, 'Biodiesel and renewable diesel', Progress in Energy and Combustion Science, vol. 36, pp. 364-373. 
Leung, DYC 2001, 'Development of a clean biodiesel fuel in Hong Kong using recycled oil', Water, Air, and Soil Pollution, vol. 130, pp. 277-282.

Mathiyazhagan, M \& Ganapathi, A 2011, Factors Affecting Biodiesel Production', Plant Biology, vol. 1, pp. 1-5.

Moser, BR 2009, 'Biodiesel production, properties and feedstocks', In Vitro Cell Dev. Biology, Plant, vol. 45, pp. 229-266.

Mushtaq, A, Ajab, KM, Muhammad, Z \& Shazia, S 2011, 'Biodiesel from non edible oil seeds: a renewable source of bioenergy', in Economics of Effects of Bio Fuel Production, ed MADS Bernades, InTech Europe.
Nielsen, F, Jongh, BHJD \& Arrakis 2011, 'Potential of castor for bio-fuel production', Available: www.fact-foundation.com.

Okullo, A, Temu, AK, Ogwok, P \& Ntalikwa, JW 2012, 'Physico-chemical properties of biodiesel from jatropha and castor oils, International Jornal of Renewable Energy Research, vol. 2, pp. 47-52.

Petracek, R 2014, 'The advantages of using biodiesel blends', viewed 24 July 2014, <http://www. streetdirectory.com/travel_guide/49884/mileage and_fuel/the_advantages_of_using_biodiesel_ blends.html>.

Shrirame, HY, Panwar NL \& Bamniya, BR 2011, 'Bio diesel from castor oil - a green energy option', Low Carbon Economy, vol. 2, pp. 1-6.

\section{Calculation for Engine Power Output}

Engine power output $(\mathrm{kW})=\frac{V \times I}{1000}$

Where, $\quad V$ is the output voltage $I$ is the output current.

\section{Calculation for Specific Fuel Consumption (SFC)}

$\operatorname{SFC}(\mathrm{ml} / \mathrm{kW})=\frac{20}{\text { Engine power output }}$

\section{Calculation for Mechanical Efficiency}

Mechanical efficiency, $\eta=\frac{B h p}{1 \mathrm{hp}} \times 100 \%$

Brake Horse Power, Bhp $(\mathrm{kW})=\frac{2 \times \pi \times \hat{n} \times T}{60 \times 10^{3}}$

Where, $\hat{n}$ is the speed in r.p.m.

Torque, $T=W \times r$

Where, $W$ is the brake load in $N$;

$R$ is the radius of the brake arm in $m$. 
Indicated Horse Power, $1 \mathrm{hp}(\mathrm{kW})=\frac{N \times \rho \times l \times a \times \eta}{1000}$

Where, $N$ is the number of strokes;

$\rho$ is the mean indicated pressure in the cylinders;

$l$ is the length of stroke;

$a$ is the cross-section area of the cylinder; and

$n$ is the number of working strokes per mm. 